\title{
KANSL1 Gene
}

National Cancer Institute

\section{Source}

National Cancer Institute. KANSL1 Gene. NCI Thesaurus. Code C102805.

This gene is involved in histone acetylation. 